\title{
Nutritionists and the comprehensive care of overweight individuals in primary care
}

\author{
O nutricionista e o cuidado integral do indivíduo \\ com excesso de peso na atenção básica
}

Ana Luisa Souza de Paiva MOURA ${ }^{1}$ iD 0000-0003-1350-7268

Elisabetta RECINE² (iD) 0000-0002-5953-7094

A B S T R A C T

\section{Objective}

This study sought to highlight the different types of challenges for the integral care of overweight individuals in primary care based on the perception of nutritionists.

\section{Methods}

This is a qualitative study with primary care professionals from the Federal District, Brazil. Semi-structured interviews were conducted to understand the perceptions regarding the organization of integral care. The analysis of the data was based on the theoretical framework Theoretical Domains Framework.

\section{Results}

Challenges related to 10 of the 12 different domains proposed by the theoretical framework were identified. These challenges are related to the capability, opportunity and motivation of workers to act to offer more effective care.

\section{Conclusion}

The different nature of the barriers identified were overlapped, which reveal the need for professional qualification along with the consolidation of an appropriate care model for chronic noncommunicable diseases such as obesity.

Keywords: Delivery of health care. Integrality in health. Nutritionist. Obesity, Primary health care.

\footnotetext{
${ }^{1}$ Ministério da Saúde, Coordenação Geral de Alimentação e Nutrição, Departamento de Atenção Básica. Brasília, DF, Brasil.

2 Universidade de Brasília, Faculdade de Ciências da Saúde, Departamento de Nutrição, Brasil. Campus Universitário Darcy Ribeiro, s/n., 70297-400 Brasília, DF, Brasil. Correspondence to: E RECINE. E-mail: <recine@unb.br>.

Article based on the dissertation by ALSP MOURA, entitled "O nutricionista e o cuidado ao indivíduo com excesso de peso na atenção básica do Distrito Federal”. Universidade de Brasília; 2016.
}

How to cite this article

Moura ALSP, Recine E. Nutritionists and the comprehensive care of overweight individuals in primary care. Rev Nutr. 2019;32e190008. http://dx.doi.org/10.1590/1678-9865201932e190008 


\section{R E S U M O}

\section{Objetivo}

Este estudo buscou compreender, a partir da percepção dos nutricionistas, as diferentes naturezas dos desafios para o cuidado integral dos indivíduos com excesso de peso na atenção básica.

\section{Métodos}

Trata-se de um estudo qualitativo com profissionais da atenção básica do Distrito Federal, Brasil. Foram realizadas entrevistas semiestruturadas, buscando compreender percepções quanto aos desafios para a organização do cuidado integral dos indivíduos com excesso de peso. Para interpretação dos dados, foi utilizada a análise de conteúdo, a partir do quadro teórico denominado Theoretical Domains Framework.

\section{Resultados}

Foram identificados desafios relacionados a 10 dos 12 diferentes domínios propostos pelo quadro teórico. Os referidos desafios estão relacionados à capacidade, à oportunidade e à motivação dos trabalhadores em agir, no sentido de ofertar um cuidado mais efetivo.

\section{Conclusão}

As diferentes naturezas das barreiras para a oferta de um cuidado iintegral dos indivíduos com excesso de peso se mostraram bastante imbricadas, apontando para uma necessidade de qualificação profissional de forma conjunta com a estruturação de um modelo de atenção adequado às condições crônicas, como o excesso de peso.

Palavras-chaves: Assistência à saúde. Integralidade à saúde. Nutricionista. Obesidade. Atenção primaria à saúde.

\section{NTRO D U C T I O N}

Being Overweight (OW) has become a chronic health problem characterized by excessive accumulation of body fat, and it is seen by some institutions as a risk factor for other complications and the disease itself [1]. Due to its multifactorial nature, its determinants are not only biological and individual, but they are also deeply related to the food environment of individuals and include a set of social, cultural, economic and historical interactions that impact the way of life of individuals and determine their habits $[2,3]$.

Effective coping with OW in the context of health services requires innovation in care delivery strategies based on multi-professional work and the design of more comprehensive care models in addition to guidance for caloric deficits. However, it is still common for professionals with low qualifications who deal with the issue to express distorted concepts and perceptions about the patient and have poor training to work with multidisciplinary teams, which leads to unsatisfactory results for both health professionals and overweight individuals [4].

The structuring of intra and intersectoral actions and strategies that promote comprehensive care are some of the measures needed to ensure more effective care. According to Mattos [5], the perspective of comprehensiveness is far beyond the attitude of professionals who assume a broader view of health needs in view of the complexity of human beings and the food environment in which they live. Understanding the etiology of problems and implementing prevention and control strategies (vertical comprehensiveness), the organization of health services (horizontal comprehensiveness) and the comprehensiveness of public policies through intersectoral actions are important aspects to consider.

Primary Care is a fundamental locus for prevention and care for overweight individuals due to its high degree of scope and connection with the population. Health care relationships established 
between teams and healthcare users allow a better understanding of the determinants of weight gain and the organization of prevention and control actions of OW [6]. Several guidelines have been published by the Ministry of Health seeking to qualify health care, however, its implementation still faces barriers in the daily routine of healthcare services that put at risk the effectiveness of strategies developed by health teams $[7,8]$.

The perception and attitudes of health professionals regarding OW are crucial for effective care. However, it has been observed that knowledge and practices are still surrounded by stigma and misinterpretation $[9,10]$. The degree of knowledge on the subject and motivation, beliefs, and attitudes of the professionals as well as the organization of work are factors that impact professional practice, bringing elements of social psychology closer to understand the reality of health care [11].

The healthcare approach for overweight individuals is still focused on changing eating habits and increasing physical activity practice. It also identifies an expectation of responsibility focused on the nutritionist, which poses challenges both in achieving results and the possible action between different professionals of the health team. The barriers and challenges faced by the nutritionist for the prevention and treatment of OW reveal complex scenarios that are also probably experienced by other health professionals $[4,6]$.

Given the complex etiology and care of OW, the aim of this study was to identify the main barriers and challenges for the achievement of comprehensive care for overweight individuals in primary care from the perspective of nutritionists by using a methodology that allows a more thorough evaluation of the phenomenon.

\section{METHODS}

This is a qualitative study. An invitation letter was sent by email to all nutritionists working in primary care in the Federal District who, upon agreement to participate, were interviewed using semi-structured interviews. Participants who agreed to participate in the study signed an informed consent and an "authorization term for the use of sound and image for research purposes", and they were interviewed face-to-face. The interviews, conducted between May and July 2016, were recorded and later transcribed for analysis.

The interview script was pre-tested with five primary care professionals from other cities in the country to refine the instrument before applying it to the participants of the research. The interview began by reading the elements of primary care for comprehensive care for overweight individuals as established by the Ministry of Health [7,8], as follows: adequate embracement of individuals, continuous analysis of food and nutritional status and its determinant factors, health promotion and obesity prevention, self-care support strategies, multi-professional care, multi-professional care for individuals undergoing bariatric surgery and referral to other healthcare services.

After reading the elements, the professionals were asked a series of questions about the main barriers and challenges in their current work context. The Theoretical Domains Framework (TDF), proposed by Michie et al. [11], was used as a theoretical reference to prepare the questions. This model aims to analyze the main factors that influence behavior and professional performance from the perspective of different behavior theories. These factors, initially grouped into 14 domains and later regrouped into 12 domains after the validation study, represent the different natures of these factors: related to intentions, individual capacity or the professional's work environment [12]. 
The questions were prepared within each domain following Michie's proposal [11] in which constructs are related to each domain (Chart 1) and relevant content examples are expected in each domain, as proposed by Heslehurst [13].

The 12 proposed domains can be concisely analyzed from the "COM-B" model proposed by the author who proposed the TDF, which groups the domains into three main dimensions: capability, opportunity to act and motivation to act. The model was used to optimize the interpretation of results and guide discussion [14]. Another author, Schwartz [15], states that the way people engage in managing work goals is a dynamic process that implies an integration between "knowing how to act" - knowing former norms -, "wanting to act" - feeling motivated or joining a collective project - , and "being able to act" - the ability to deal with the environment. These elements correspond to the dimensions and domains of TDF and COM-B. The domains, their definitions, research use and related constructs are described in Chart 1.

Chart 1. Theoretical Domains Framework definitions, constructs and use in research with primary healthcare nutritionists in the Federal District, Brazil, 2016.

1 of 2

\begin{tabular}{|c|c|c|c|}
\hline Domain & Constructs & Definition & Use in research \\
\hline Knowledge & $\begin{array}{l}\text { Knowledge; procedural knowledge; } \\
\text { knowledge of task environment. }\end{array}$ & $\begin{array}{l}\text { Knowledge of the existence of some- } \\
\text { thing, an evaluation based on the } \\
\text { expression of having or not knowing } \\
\text { about procedures or certain behaviors. }\end{array}$ & $\begin{array}{l}\text { Knowledge of the guidelines or } \\
\text { protocols that organize care as } \\
\text { given as well as knowledge of how } \\
\text { to carry out each of the actions in } \\
\text { care. }\end{array}$ \\
\hline Abilities & $\begin{array}{l}\text { Skills; Skill development; Competence; } \\
\text { Aptitude; Interpersonal Skills; Practice; } \\
\text { Skill assessment. }\end{array}$ & $\begin{array}{l}\text { Aptitude or proficiency acquired } \\
\text { through practice, which is identified } \\
\text { from expressions that describe } \\
\text { techniques and skills used in carrying } \\
\text { out the actions. }\end{array}$ & $\begin{array}{l}\text { Interpersonal skills (empathy, practice, } \\
\text { sensitivity, non-judgmental, patient } \\
\text { approach, etc.) as well as skills } \\
\text { adopted as an alternative due to } \\
\text { the lack of adequate training. }\end{array}$ \\
\hline $\begin{array}{l}\text { Social or } \\
\text { professional } \\
\text { role and } \\
\text { identity }\end{array}$ & $\begin{array}{l}\text { Professional identity; Role of the } \\
\text { professional; Socialidentity; Identity; } \\
\text { Professional limits; Professional } \\
\text { trust; Group identity; Leadership; } \\
\text { Organizational commitment. }\end{array}$ & $\begin{array}{l}\text { How professionals perceive them } \\
\text { selves, to what extent they understand } \\
\text { that carrying out those actions is their } \\
\text { professional or social responsibility, } \\
\text { how much their personal identity } \\
\text { influences performance of that action } \\
\text { or behavior. }\end{array}$ & $\begin{array}{l}\text { The degree to which professionals } \\
\text { feel that their performance of actions } \\
\text { is their attribution, and the influence } \\
\text { of perception of their identity for the } \\
\text { development of actions. }\end{array}$ \\
\hline $\begin{array}{l}\text { Beliefs about } \\
\text { abilities }\end{array}$ & $\begin{array}{l}\text { Self-efficacy; Perceived skills; Self- } \\
\text { confidence; Beliefs; Empowerment; } \\
\text { Self-esteem; Perceived behavioral } \\
\text { control; Professional trust. }\end{array}$ & $\begin{array}{l}\text { Associated with acceptance of truth } \\
\text { and validity about a skill or talent } \\
\text { that professionals have and use for } \\
\text { something. }\end{array}$ & $\begin{array}{l}\text { Perceived capacity of professionals } \\
\text { to perform actions. }\end{array}$ \\
\hline Optimism & $\begin{array}{l}\text { Optimism; Pessimism; Unreal optimism; } \\
\text { Identity. }\end{array}$ & $\begin{array}{l}\text { Confidence that actions will be } \\
\text { considered good and desired goals } \\
\text { will be achieved, or the opposite } \\
\text { (associated with the pessimism con- } \\
\text { struct). }\end{array}$ & $\begin{array}{l}\text { Expressions that identify if the actions } \\
\text { performed are something positive } \\
\text { or even the opposite. }\end{array}$ \\
\hline $\begin{array}{l}\text { Beliefs about } \\
\text { consequences }\end{array}$ & $\begin{array}{l}\text { Beliefs; Expectation of results; Charac- } \\
\text { teristics of outcome expectations; } \\
\text { Early repentance; Consequences. }\end{array}$ & $\begin{array}{l}\text { Acceptance of truthfulness and validity } \\
\text { about the consequences or results of a } \\
\text { behavior in a given situation. }\end{array}$ & $\begin{array}{l}\text { Expressions indicating that profes- } \\
\text { sionals believe that performing or } \\
\text { not the given set of actions will } \\
\text { have consequences for themselves, } \\
\text { the team or the individual. }\end{array}$ \\
\hline
\end{tabular}


Chart 1. Theoretical Domains Framework definitions, constructs and use in research with primary healthcare nutritionists in the Federal District, Brazil, 2016.

\begin{tabular}{|c|c|c|}
\hline Domain & Constructs & Definition \\
\hline Reinforcement & $\begin{array}{l}\text { Rewards (proximal/distal; valued/ } \\
\text { not valued; probable/unlikely); } \\
\text { Incentives; Punishment; Results/ } \\
\text { effects; Reinforcement; uncertainty; } \\
\text { sanctions. }\end{array}$ & $\begin{array}{l}\text { Increased probability of a response } \\
\text { from the relationship between the } \\
\text { existence of a given stimulus and the } \\
\text { occurrence of that response. Related } \\
\text { to associative learning. }\end{array}$ \\
\hline Intentions & $\begin{array}{l}\text { Stability of intentions; Behavior } \\
\text { change models; Transtheoretical } \\
\text { model and stages of change. }\end{array}$ & $\begin{array}{l}\text { It is a conscious decision to perform } \\
\text { a behavior or the decision to act } \\
\text { in a particular direction. It is more } \\
\text { related to willingness to start or end } \\
\text { a behavior. }\end{array}$ \\
\hline
\end{tabular}

Objectives Objectives (distal and proximal); It is related to a future scenario Objective priorities; Establishment toward which individuals focus on of objectives/goals; Objectives their actions, i.e. the purpose of the (autonomous or controlled)Action activities or efforts used. planning; Implementation of intention.

Memory, Memory; Attention; Attention The ability to retain information, attention control; Decision making; Cognitive selectively focus on aspects of the and decision exhaustion/tiredness. environment, and choose between processes

Environmental Material resources/resources; Envi- Any circumstance associated with context and ronmental stressors; Culture; Organ- a situation or environment that resources izational environment; Salient encourages or discourages the events/critical incidents; Person x development of skills, independence, environmental interaction; Barriers social competence or adaptive and facilitators.

Social influence

Emotions
Social pressure; Social norms; Group Interpersonal processes that compliance; Social comparisons; influence the change of thoughts, Group norms; Group support; Power; feelings or behaviors of individuals. Intergroup conflicts; Alienation; Interactions that influence behavior Group identity; Modeling.

Affection; Stress; Depression; Fear; Patterns of complex reactions that Burn out; Positive/negative affect; involve behavioral, psychological and Anxiety.

Self-monitoring; Breaking habits; Action planning. experiential elements by which the or event.

Anything aimed to organize, manage or objectively change certain actions. two or more behavioral alternatives.

Assertiveness about situations in which professionals remember or forget to perform the planned actions; Cognitive approaches to performing a behavior or making a quick decision; Cognitive limitations such as forgetting or not being able to make a particular decision regarding integral care. behavior.

Expressions indicating that carrying out the proposed set of actions is associated with some reward or punishment, e.g. from unit management, team members, etc.

much the professional is willing for the care of the overweight individual and how much these actions are prioritized.

Expressions that indicate possible goals that will be achieved in comprehensive care for overweight individuals.

The statement of absence or presence, or even the expression of the desire for presence, equipments, resources, services organizational structure that facilitates or prevents care to individuals are environmental context factors and resources that influence the professional's behavior.

Assertiveness that shows that a relationship risks the development of actions or even that the form of interaction with the patient may condition the completion or not of care in an integral way.

Expressions of emotional reactions or emotional states in view of the actions.
Assertiveness in which professionals want assessment or feedback of behavior, or when referring to necessary or ongoing processes to monitor the performance of action, i.e. conscious efforts that regulate behavior 
The interviews were transcribed verbatim in Microsoft Word and imported into the nVIVO software. (Version 10, Melbourne, Australia) [16]. The interviews were analyzed based on the identification of the domains defined by the TDF. All content and meanings were analyzed using the content analysis technique proposed by Bardin [17]. The recording units were identified and categorized according to the themes that emerged during the interviews, using the categories predefined by the TDF as well as the expected constructs within each domain. Thus, the recording units were categorized in their respective domains regardless of the order or time they appeared in the interview. The questions only helped guide the interview and approach relevant aspects.

The project was approved by the Research Ethics Committee of the School of Health of the University of Brasilia (CEP-FS/UNB) and the Ethics Committee of the co-participating institution, (FEPECS/SES/DF) (Reports n. 1.524.237 and 1.559.798, respectively).

\section{RESULTS AND DISCUSSION}

The convenience sample included 16 of the 75 nutritionists who work in primary care of the Federal District, Brazil, and agreed to participate in the interview. Analysis of the profile of those who responded positively to the invitation letter showed that they represented all the health regions in the Federal District, Brazil, thus assuming that the 16 professionals would provide an overview of the situation of primary care in the Federal District and all its territorial particularities.

Participants ages ranged from 27 to 54 years and most of them were women $(n=14)$. Training time ranged from 4 to 29 years and length of service at the current workplace ranged from 3 to 10 years.

According to the current workplace, seven professionals worked in traditional primary care; five in support of the Estratégia Saúde da Familia (ESF, Family Health Strategy), that is, professionals connected to a primary care setting who meet the demands from family health teams, but who are not formally part of a multi-professional team such as Núcleos de Apoio à Saúde da Família (NASF, Centers for Family Health-Related Support) and four from NASF. The domains identified and the main barriers to integral care for overweight individuals, according to the TDF, are shown in Chart 2.

The Theoretical Domains Framework has proven to be a useful tool for a systematic approach to identify barriers in work processes, contributing to the planning of more effective interventions by recognizing that barriers have different natures and therefore require different interventions. In this research, the model was used to identify which barriers impact the possibility of performing comprehensive care for overweight individuals in primary care $[18,19]$.

Of the 12 domains analyzed, barriers and challenges were identified in all domains, except in the "objective" and "intention" domains where all participants agreed that the goal of providing comprehensive care is necessary and urgent and they would like to be able to achieve it.

Regarding the first component, "capacity" ("know-how"), barriers were identified regarding the domain "knowledge". The lack of knowledge of the actions presented as a scope of comprehensive care was observed, revealing a gap between the standards published by the Ministry of Health and their application. A similar study on nutritional overweight assessment in Santos, São Paulo, also showed that only $14 \%$ of the interviewed professionals used the Ministry of Health technical manuals to guide their practices [20]. 
Chart 2. Barriers and challenges for comprehensive health care of overweight individuals according to the Theoretical Domains Framework (TDF). Federal District, Brazil, 2016.

\begin{tabular}{|c|c|c|}
\hline $\begin{array}{l}\text { Component of } \\
\text { "COM-B" }\end{array}$ & Behavior domain & Challenge/Barrier \\
\hline \multirow{10}{*}{$\begin{array}{l}\frac{\vec{T}}{\overline{0}} \\
\frac{0}{0} \\
\frac{0}{0} \\
0\end{array}$} & \multirow{3}{*}{ Knowledge } & $\begin{array}{l}\text { Unawareness of actions defined for primary care in the context of integral care, both as a } \\
\text { whole and isolated actions. }\end{array}$ \\
\hline & & Recognition of the proposal by similarity with the work done. \\
\hline & & Unawareness of the flow in the Health Care Network to achieve comprehensive care. \\
\hline & \multirow{3}{*}{ Skills } & Difficulty working as a team. \\
\hline & & Difficulties in approaching the patient. \\
\hline & & Inability to manage individuals who have undergone bariatric surgery. \\
\hline & \multirow{4}{*}{$\begin{array}{l}\text { Behavioral } \\
\text { Regulation }\end{array}$} & Lack of team planning. \\
\hline & & No protocol for health care. \\
\hline & & Lack of personal organization. \\
\hline & & Failure to demand from the chief. \\
\hline
\end{tabular}

Social Influences

Work misalignment among the team.

Devaluation of the nutritionist by the team.

Relational criticism and conflict.

Environmental
Context and
Resources
$\frac{7}{\frac{2}{2}}$
$\frac{0}{0}$

Low compromise of management.

Inadequate and insufficient physical space to perform actions.

Lack of resources and materials.

Health care network and non-consolidated care model.

Shortage of professionals.

Imbalance between demands and available workload.

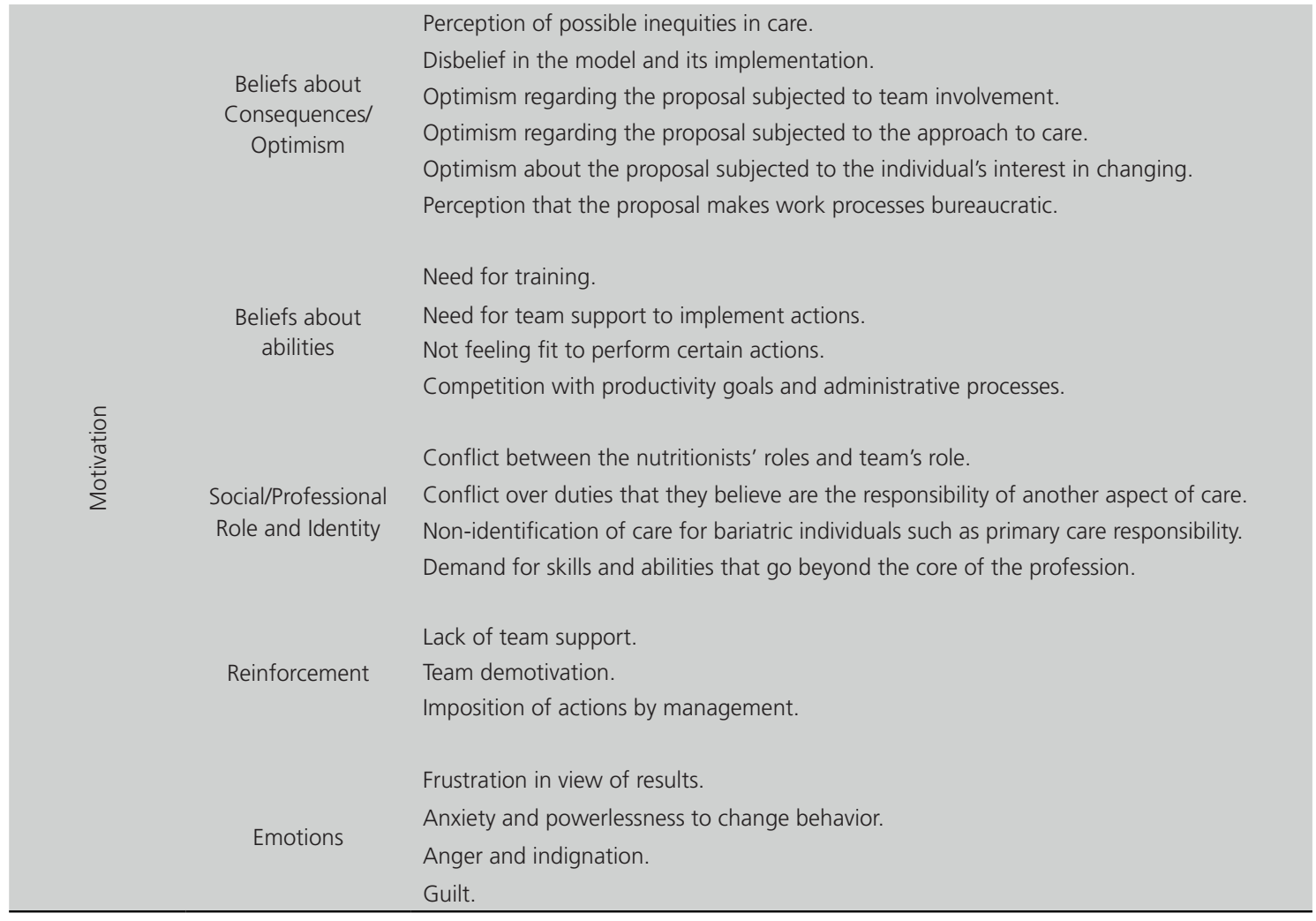


It is a consensus that the training process of health professionals should be guided towards the demands and logic of Sistema Único de Saúde (SUS, Unified Health System), care, especially since it is their responsibility to train human resources. However, as highlighted by Araújo et al. [21], the prevailing idea regarding training is still based on an individualized and segregated logic, poorly included in the healthcare network, distant from the perspective of integrality, and that carries little transformative potential for the complex reality of individuals and community.

It has been suggested that there is little evidence-driven practice regarding its effectiveness in coping with OW and highly dependent on empiricism of accumulated experiences. A similar result was found in a study on Evidence-Based Practice (EBP) of NASF professionals in the city of São Paulo revealed that, although professionals recognize the importance of EBP, the daily routine of service is still focused on the clinical experience and, to a lesser extent, on scientific evidence and preference for individual care [22]. Practice poorly guided by scientific evidence often leads to failure of professionals when addressing overweight individuals, such as temporary change in eating habits, limited weight loss, discontinuity, frustration and anxiety - as identified in the "emotions" domain of the "motivation" component.

You know, I think embracement, as I do almost everything empirically because we didn't take a course: "Just embrace patients and etc." So, I think I know how to embrace [...] promotion actions are kind of vague, I do promote actions and other things (TRAD4).

The feeling is of frustration, I will not lie, and I ask myself: "Why didn't the patient make it? Didn't I give the patient the right kind of information?" (ESF2).

Pedagogical projects that develop skills and competences that combine these dimensions - knowledge and doing -, and increase the qualified performance of the nutritionist in SUS are imperative $[23,24]$. Working within the perspective of comprehensive care requires the professional to break with the hegemonic model of training, open space for reflective processes that lead to the transformation of professional practices and organize work to respond to the needs of people and the population [21] .

The barriers identified within the "skills" domain reflect the difficulty of associating practices and intra and interprofessional knowledge. As for the difficulty in managing teamwork, a study conducted in Sobral (CE), Brazil, showed that the performance of nutritionists is often acknowledged by the team and management as clinical care, and it is poorly integrated with other professionals. The study reaffirms that the difficulty of teamwork is revealed when nutritionists often see themselves either as those who must be in charge of productivity when caring for patients, or handle demands from other professionals, or as a professional who helps "relieve" the workload of others [25]. The lack of training of nutritionists to plan and organize care is a gap that has been identified in the Pedagogical Projects of Nutrition [26].

Difficulties in approaching patients is rooted in the conflict between the field and knowledge core. This limits performance in specific, isolated practices and generally around "core competencies" of each professional category.

[...] because reality of patients requires understanding their psychology, we find ourselves facing difficult realities and we do not have training for that; the patient needs an answer to statements such as: "What can I do, I have no money, I have lost my job..." (TRAD2).

The demand for comprehensive interdisciplinary practice that is closer to the users' needs requires the integration not only of knowledge, but also of practice that combines multiplicity 
and specialization [27]. Embracement is one of the essential characteristics of primary care, so embracement individuals, their life history and complex reality is the responsibility of all professionals and not the responsibility of specific categories of professionals.

Similarly, the attitude of professionals towards individuals also has an impact on care outcomes. Studies assessing the effectiveness of actions for the prevention and treatment of OW reveal negative results, indicating that the difficulty in approaching the patient, demonstrated in negative attitudes of professionals during the care process, often characterized by blame and prejudiced approach, influence the poor results $[28,29]$.

Another barrier identified was the inability to follow up individuals undergoing bariatric surgery. Follow-up has not been frequently performed by primary care professionals, which causes a bottleneck effect in hospital or outpatient care and hinders planning of therapeutic care and closer follow up in primary care [30]. Being responsible for the primary care of individuals undergoing bariatric surgery - after necessary follow-up by specialized care -, can increase the chances of successful maintenance of weight loss and prevent weight regain by broadly and contextually considering the multiple risk factors of individuals under care.

Regarding the "behavioral regulation" domain, the need to motivate leadership and the difficulty in team's planning were identified as a barrier, which prevent the definition of priorities, schedule, flow and duties as well as the perception of lack of personal organization and protocol. The non-recognition of flow, lack of knowledge of duties in different aspects of health care and the lack of communication within the network have been pointed as examples of barriers that lead professionals to seek for informal strategies within the healthcare network or even inaction [21].

[...] there is no flow chart, when patients arrive, they don't know where to go, you know? This lack of organization is a burden (TRAD 2).

The results of the "capacity" component are closely related to the themes that emerged in the "opportunity" component, which includes external barriers for the professional. In this component, the center of debate is not only the individual ability to work in teams, but the focus of teamwork itself and the resources available at work. The way the team relates - criticism, professional devaluation, low management commitment -, and the resources available to perform work impact how the professional will act. A study on the perception of primary healthcare professionals in a municipality of São Paulo on the organization of teamwork shows that, despite efforts to seek the logic of comprehensiveness, biomedical care is still predominantly focused on clinical diagnosis and treatment, medication, difficulty in organic integration of some professionals in the team and individualization of performance of different professionals, which shows a distance between "desirable" practice and what is effectively in practice [31].

The perception of a fragmented system marked by conflict of different interests (political, institutional, management as well as the team) and non-transparent operating logic reveal the impact on the care processes. Comprehensive care for OW individuals goes beyond a model marked by discontinuity of care, lack of planned actions, greater appreciation of curative and prescriptive actions, emphasis on productivity as a quality criterion and precarious health surveillance of the population [32]. Although the family health model has gaps in its implementation, it has characteristics that favor bonding, embracement, focus on family, continuity, multi-professional approach, expansion of service provision and health promotion [27, 33]. 
Despite relational barriers and work processes, it is clear that integrated and multi-professional work is seen as necessary for effective and integral care, which includes the institutionalization of communication and sharing of practices and knowledge, is fundamental for the professionals agenda, planning, listening, discussions, sharing and coordinated team evaluation [34]. Aspects of the environmental context and identified resources are structural bottlenecks of SUS, which include insufficient materials and adequate physical spaces, work overload due to lack of professionals, emphasis on productivity, and procedures [35]. A study conducted in São Paulo, (SP) on the implementation of guidelines for comprehensive care for diabetes melittus and hypertension, similar to the proposal for obesity, also showed the lack of coordination between the points of the healthcare network, low adherence to existing care protocols, low provision of health promotion actions and lack of knowledge of the instruments for care planning [36].

Aspects of the "opportunity" component impact the "motivation" component. The structural and organizational deficiencies of the team are shown as conditioning factors for the positive perception of the consequences of integral care. Although they agree that the theoretical objective of the proposal is positive, they attribute its effectiveness to these factors.

The proposal is fantastic and wonderful, if one had a coordinator who took care of it, made it work, motivated it, then motivation of professionals would be 100\% if it worked. But no, it's just on paper (TRAD5).

Regarding the "beliefs about consequences/optimism" domain, in addition to the contextual aspects of work, individuals and their willingness to change are a condition for the effectiveness of care.

It would not work [...] because if the individual does not understand what needs to be changed [...] it does not matter what we do, it will not solve the problem, will it? (ESF1).

Changing lifestyle habits, despite being at the core of the process of caring for the OW, are conditioned by several proximal and distal factors of the individual, in a way that many of these habits are not even under their control to change. The process of change, even if carried out by the individual, can be worked out together with health professionals and the approaches and strategies used by them can also help or hinder the individual during change. The professionals' understanding of the problem and their attitudes towards the care process have a profound impact on treatment and, consequently, on the individual adherence to the process of change [37]. Cori's Study [38] showed that nutritionists had a limited understanding of the determinants of obesity with a predominance for a biological approach, which directly impacts the effectiveness of care provided by these professionals.

Another important barrier, in the motivational scope, is related to the "social/professional role and identity" domain. The misalignment of work among health professionals exposes a misalignment in the team's social identity that can affect both concrete and visible work as well as the subjective dimensions of the professional's performance, revealing the psychological dimension of what teamwork means [39]. The conflict between individual responsibility vs. team responsibility, team responsibility vs. responsibility of other healthcare settings is the lack of clarity of performance limitations that reflect a gap in the professionals' training when working at SUS and within the healthcare network. A study on the planning of actions for coping with OW in the city of Rio de Janeiro, $(\mathrm{RJ})$, revealed the fragmentation of roles within the health team, in which different professionals had different understandings of OW and consequently about who would be responsible for care [40]. 
In order to provide comprehensive care for overweight individuals, a multi-professional approach and management support in the organization of work processes is required. However, beyond a structural barrier, as previously discussed, this challenge is also a source of demotivation for continuing care provided by professionals, albeit in a fragmented way.

What discourages me is knowing that I do not have any support from a team, you know? [...] My boss says: "Do whatever you want to do on your time". But to what extent is this support for this type of proposal? (ESF4)

Finally, aspects related to demotivation, anxiety, feeling of helplessness, frustration, anger, indignation and guilt impact professional practices, regardless if they are appropriate or not, on the psychic dimension of health workers. A study conducted on primary healthcare professionals from Sapucaia do Sul, (RS), Brazil, showed that the difficulty in creating bonds with individuals, in thinking of innovative strategies for behavior change, preconceived judgments (labeling chronic individuals as "complicated") and ineffective strategies cause feelings of frustration and a vicious cycle of demotivation [41].

\section{CONCLUSION}

This study showed that the challenges faced by professionals to ensure comprehensive care for overweight individuals are multiple and of different natures, reflecting barriers in relation to the ability to act, the fragility of the organization of teamwork processes and motivation itself in view of the challenge of integral care.

In the present study, we discussed several limitations, which do not allow any further conclusions. The study was based on a convenience sample and the invitation was sent to $100 \%$ of the professionals working in primary care. There were no indications at that time that any health units, teams or professionals were outstanding for obesity care. Thus, considering that patients in the Federal District seek the most accessible healthcare unit, irrespective of their health demands, it was considered appropriate to send the invitation to all professionals to have a broader idea of care available. There may be a bias in the results given that those who responded to the invitation are somehow more closely related to the theme, either because they are more interested or even because they face greater challenges.

The studies that support the discussion have shown that there are common elements in the challenges faced by primary care in different Brazilian municipalities to organize more comprehensive care for individuals with chronic conditions, particularly OW. Similarly, identifying that many of the challenges are not restricted to specific characteristics of nutritionists, but related to the entire health team, points to the need to consolidate a care model and organize work processes of primary care that respond more effectively to the health demands of individuals and populations.

The TDF allowed a more qualified analysis of the challenges for structuring comprehensive care for overweight individuals in primary care, corroborating to understand that the barriers have different natures and, therefore, need different overcoming measures. A more accurate view allows the design of implementation strategies for comprehensive care that are not restricted to professional qualification, for example, as if the only limitation for effective care was a need for technical knowledge or development of individual skills. Using the TDF allowed the identification of a barrier in the field of knowledge, skills and attitudes, but they are intertwined with the need for organization and work qualification of the team and healthcare network, which are aspects that equally impact the subjectivity (motivation) of professionals and consequently their performance. 
CONTRIBUTORS

ALSP MOURA contributed to the study design, data collection, analysis and writing of the manuscript. E RECINE contributed to the study design, writing and review of the manuscript.

\section{REFERENCES}

1. Kyle TK, Dhurandhar EJ, Allison DB. Regarding obesity as a disease: Evolving policies and their implications. Endocrinol Metab Clin North Am. 2016;45(3):511-20. http://dx.doi.org/10.1016/j.ecl.2016.04.004

2. Jaacks LM, Vandevijvere S, Pan A, McGowan CJ, Wallace C, Imamura F, et al. The obesity transition: Stages of the global epidemic. Lancet Diabetes Endocrinol. 2019;7(3):231-40. http://dx.doi.org/10.1016/S2213-8 587(19)30026-9

3. Kleinert S, Horton R. Rethinking and reframing obesity. Lancet. 2015;385(9985):2326-8. http://dx.doi. org/10.1016/S0140-6736(15)60163-5

4. Dietz WH, Baur LA, Hall K, Puhl RM, Taveras EM, Uauy R. Management of obesity: Improvement of health-care training and systems for prevention and care. Lancet. 2015;285(9986):2521-33. http://dx.doi.org/10.1016/S 0140-6736(14)61748-7

5. Mattos RA. Os sentidos da integralidade: algumas reflexões acerca de valores que merecem ser defendidos. In: Pinheiro R, Mattos RA, organizadores. Os sentidos da integralidade na atenção e no cuidado à saúde. Rio de Janeiro: Associação Brasileira de Saúde Coletiva; 2001. p.39-64.

6. Almeida LM, Campos KFC, Randow R, Guerra VA. Estratégias e desafios da gestão da Atenção Primária à Saúde no controle e prevenção da obesidade. Revista Eletr Gestão Saúde. 2017;8(1):114-39.

7. Ministério da Saúde (Brasil). Portaria $n^{\circ}$ 424, de 19 de março de 2013. Redefine as diretrizes para a organização da prevenção e do tratamento do sobrepeso e obesidade como linha de cuidado prioritária da Rede de Atenção à Saúde das Pessoas com Doenças Crônicas. Diário Oficial da União. 2013; Seção 1.

8. Ministério da Saúde (Brasil). Secretaria de Atenção à Saúde. Estratégias para o cuidado da pessoa com doença crônica: obesidade. Cadernos de Atenção Básica n 38. Brasília: Ministério da Saúde; 2014.

9. Cori GDC, Petty MLB, Alvarenga MDS. Atitudes de nutricionistas em relação a indivíduos obesos: um estudo exploratório. Ciên Saúde Coletiva. 2015;20(2):565-76. http://dx.doi.org/10.1590/1413-81232015 202.05832014

10. Francisco LV, Diez-Garcia RW. Abordagem terapêutica da obesidade: entre conceitos e preconceitos. Demetra: Aliment Nutri Saúde. 2015;10(3):705-16. http://dx.doi.org/10.12957/demetra.2015.16095

11. Michie S, Johnston M, Abraham C, Lawton R, Parker D, Walker A. Making psychological theory useful for implementing evidence-based practice: A consensus approach. Qual Saf Health Care. 2005;14(1):26-33. http://dx.doi.org/10.1136/qshc.2004.011155

12. Cane J, O'Connor D, Michie S. Validation of the theoretical domains framework for use in behaviour change and implementation research. Implement Sci. 2012;7(1):1-17. http://dx.doi.org/10.1186/1748-5908-7-37

13. Heslehurst N, Newham J, Maniatopoulos G, Fleetwood C, Robalino S, Rankin J. Implementation of pregnancy weight management and obesity guidelines: A meta-synthesis of healthcare professionals barriers and facilitators using the Theoretical Domains Framework. Obes Rev. 2014;15(6):462-86. http://dx.doi. org/10.1111/obr. 12160

14. Michie S, Van Stralen MM, West R. The behavior change wheel: A new method for characterising and designing behavior change interventions. Implement Sci. 2011;6:42. http://dx.doi.org/10.1186/1748-5908-6-42

15. Schwartz Y. Abordagem ergológica e necessidade de interfaces pluridisciplinares. ReVel. 2016;11:93-104.

16. QSR Internacional. nVIVO. Version 10.0 for Windows [software]. Melbourne, Australia; 1999-2014.

17. Bardin L. Análise de conteúdo. Lisboa: Edições 70; 2006

18. Mosavianpour M, Sarmast HH, Kissoon N, Collet, JP. Theoretical domains framework to assess barriers to change for planning health care quality interventions: A systematic literature review. J Multidiscip Healthc. 2016;9:303-10. http://dx.doi.org/10.2147/JMDH.S107796 
19. Lawton R, Heyhoe J, Louch G, Ingleson E, Glidewell L, Willis TA, et al. Using the Theoretical Domains Framework to understand adherence to multiple evidence-based indicators in primary care: A qualitative study. Implement Sci. 2016;11(1):1-16. http://dx.doi.org/10.1186/s13012-016-0479-2

20. Neves JA, Zangirolani LTO, Medeiros MAT. Evaluation of nutritional care of overweight adults from the perspective of comprehensive health care. Rev Nutr. 2017;30(4):511-24. http://dx.doi.org/10.1590/167898652017000400010

21. Araújo D, Miranda MCG, Brasil SL. Formação de profissionais de saúde na perspectiva da integralidade. Rev Baiana de Saúde Pública. 2014;31(20):20-31.

22. Ferretti F, Romancini F, Schneider LR, Ferraz L. Prática baseada em evidência no contexto dos núcleos de apoio a saúde da família em Chapecó. Cogitare Enferm. 2018;23(2);1-9. http://dx.doi.org/10.5380/ce.v23i2.52774

23. Recine E, Alves KPS, Monego E, Sugai A, Melo ACM. Formação profissional para o SUS: análise de reformas curriculares em cursos de graduação em nutrição. Rev Aval Educ Super. 2018;23(3):679-97. http://dx.doi. org/10.1590/s1414-40772018000300007

24. Teixeira F, Pais-Ribeiro JL, Maia Â. Uns desistem, outros insistem: semelhanças e diferenças no discurso de profissionais de saúde face à obesidade. Rev Port de Saúde Pública. 2015;33(2)137-47. http://dx.doi. org/10.1016/j.rpsp.2015.07.002

25. Barbosa MIS, Leonardo GDMN, Bosi MLM. O nutricionista na estratégia saúde da família: estudos socioculturais em alimentação e saúde: saberes em rede. Rio de Janeiro: Editora UERJ; 2016.

26. Alves CGL, Martinez MR. Lacunas entre a formação do nutricionista e o perfil de competências para atuação no Sistema Único de Saúde. Interface. 2016;20(56):159-69. http://dx.doi.org/10.1590/1807-57622014.1336

27. Fertonani HP, Pires DEPD, Biff D, Scherer MDDA. The health care model: Concepts and challenges for primary health care in Brazil. Ciên Saúde Colet. 2015;20(6):1869-78. http://dx.doi.org/10.1590/1413-81 232015206.13272014

28. Blackburn M, Stathi A, Keogh E, Eccleston C. Raising the topic of weight in general practice: Perspectives of GPs and primary care nurses. BMJ Open. 2015;5(8):1-10. http://dx.doi.org/10.1136/bmjopen-2015-008546

29. Epstein L, Ogden J. A qualitative study of GPs' views of treating obesity. Br J Gen Pract. 2005;55(519):750-4.

30. Rossetti FX, Lorenzi MN, Gomes KSG. Aspectos nutricionais e qualidade de vida após cirurgia bariátrica em pacientes da atenção primária à saúde. Segur Aliment Nutr. 2017;24(1):75-82. http://dx.doi.org/10.20396/ san.v24i1.8649757

31. Carrapato JFL, Castanheira ERL, Placideli N. Percepções dos profissionais de saúde da atenção primária sobre qualidade no processo de trabalho. Saúde Soc. 2018;27(2):518-530. http://dx.doi.org/10.1590/S010412902018170012

32. Rodrigues MP, Melo RHV, Vilar RLA, Silva GSN, Silva AB. Ressignificando o trabalho na Estratégia Saúde da Família: desafios para a integralidade do cuidado em saúde. R-bits. 2017;7(2):32-44. http://dx.doi. org/10.18816/r-bits.v7i2.6768

33. Giovanella L, Mendonça MHM, Almeida PF, Escorel S, Senna MCM, Fausto MCR, et al. Saúde da família: limites e possibilidades para uma abordagem integral de atenção primária à saúde no Brasil. Ciênc Saúde Coletiva. 2009;14(3):783-94. http://dx.doi.org/10.1590/\$1413-81232009000300014

34. Gavalote HS, Franco TB, Freitas PSS, Lima EFA, Garcia ACP, Andrade MAC, et al. A gestão do trabalho na estratégia saúde da família: (des)potencialidades no cotidiano do trabalho em saúde. Saude Soc. 2016; 25(4):988-1002. http://dx.doi.org/10.1590/S0104-12902016158633

35. Jaccoud L, Vieira FS. Federalismo, integralidade e autonomia no SUS: desvinculação da aplicação de recursos federais e os desafios da coordenação. Rio de Janeiro: Instituto de Pesquisa Econômica Aplicada, 2018.

36. Venancio SI, Rosa TEDC, Bersusa AAS. Atenção integral à hipertensão arterial e diabetes Mellitus: implementação da linha de cuidado em uma região de saúde do estado de São Paulo, Brasil. Physis. 2016;26(1):113-35. http://dx.doi.org/10.1590/S0103-73312016000100008

37. Teixeira FV, Pais-Ribeiro JL, Maia, ÂRPC. Crenças e práticas dos profissionais de saúde face à obesidade: uma revisão sistemática. Rev Assoc Med Bras. 2012;58(2):254-62. http://dx.doi.org/10.1590/S0104-42 302012000200024

38. Cori GDC, Petty MLB, Alvarenga MDS. Atitudes de nutricionistas em relação a indivíduos obesos: um estudo exploratório. Ciên Saúde Coletiva. 2015;20(2):565-76. http://dx.doi.org/10.1590/1413-81232015202.058 32014 
39. Arantes LJ, Shimizu HE, Merchán-Hamann E. Contribuições e desafios da Estratégia Saúde da Família na Atenção Primária à Saúde no Brasil: revisão da literatura. Ciên Saúde Coletiva. 2016; 21(5):1499-510. http:// dx.doi.org/10.1590/1413-81232015215.19602015

40. Cavalcante EFL. Planejamento e coordenação de ações de alimentação e nutrição: enfrentamento do sobrepeso e da obesidade no município do Rio de Janeiro [tese]. Rio de Janeiro: Escola Nacional de Saúde Pública Sergio Arouca; 2017.

41. Silocchi $C$, Junges JR. Equipes de atenção primária: dificuldades no cuidado de pessoas com doenças crônicas não transmissíveis. Trab Educ Saúde. 2017;15(2):599-615. http://dx.doi.org/10.1590/1981-7746-sol00056

Received: March 3, 2019

Final Version: July 16, 2019

Approved: October 3, 2019 